See discussions, stats, and author profiles for this publication at: https://www.researchgate.net/publication/321424552

\title{
THE RELATIONSHIP OF READING INTEREST AND LEARNING MOTIVATION WITH NEWS WRITING SKILLS OF GRADE VIII STUDENTS SMP N 24 PADANG
}

Article $\cdot$ March 2015

DOI: 10.24036/komposisi.v16i1.8046

40

3 authors, including:

Atmazaki Atmazaki

Situs Resmi Universitas Negeri Padang

15 PUBLICATIONS 8 CITATIONS

SEE PROFILE

Some of the authors of this publication are also working on these related projects: 
Komposisi:

Jurnal

Pendidikan

Bahasa, Sastra,

dan Seni

Volume XVI

Nomor 1

Maret 2015

Hal. 79-90

\section{THE RELATIONSHIP OF READING INTEREST AND LEARNING MOTIVATION WITH NEWS WRITING SKILLS OF GRADE VIII STUDENTS SMP N 24 PADANG}

\section{HUBUNGAN MINAT BACA DAN MOTIVASI BELAJAR DENGAN KETERAMPILAN MENULIS BERITA SISWA KELAS VIII SMP NEGERI 24 PADANG}

\author{
$\mathrm{Ria}^{1)}$, Atmazaki $^{2)}$, Abdurahman $^{3)}$ \\ Program Pascasarjana Universitas Negeri Padang \\ ria@yahoo.com
}

\begin{abstract}
This study aims to explain the following. First, the relationship of reading interest, news writing skill of grade VIII students SMP Negeri 24 Padang. Secondly, the relationship between learning motivation with news writing skills of grade VIII students. Third, the relationship between reading interest and learning motivation with news writing skills of grade VIII students. The population was grade VIII students. Samples are 40 students grade VIII students SMP Negeri 24 Padang performed using proportional random sampling technique. Data were collected through questionnaires and performance tests. Questionnaire was used to see interest in reading and students' motivation, while performance tests conducted to determine the outcome of news writing skills of students. Analysis and discussion of the data is done in accordance with the concept of descriptive correlational study. Based on the research conducted can be summarized as the follows. First, there is a significant correlation between reading interest, the news writing skills of grade VIII students SMP Negeri 24 Padang. Secondly, there is a significant relationship between learning motivation and news writing skill of grade VIII students. Third, there is a significant relationship between interest in reading and learning motivation together with news writing skills students.
\end{abstract}

Key Words: reading, learning motivation, news writing skills

\title{
Abstract
}

Penelitian ini bertujuan untuk menjelaskan hal-hal berikut. Pertama, hubungan minat baca, keterampilan menulis berita siswa kelas VIII SMP 
Negeri 24 Padang. Kedua, hubungan antara motivasi belajar dengan kemampuan menulis berita siswa kelas VIII. Ketiga, hubungan antara minat membaca dan motivasi belajar dengan keterampilan menulis berita siswa kelas VIII. Populasi siswa kelas VIII. Sampel sebanyak 40 siswa kelas VIII SMP Negeri 24 Padang dilakukan dengan teknik proportional random sampling. Data dikumpulkan melalui kuesioner dan tes kinerja. Kuesioner tersebut digunakan untuk melihat minat membaca dan motivasi siswa, sedangkan tes kinerja dilakukan untuk mengetahui hasil keterampilan menulis berita siswa. Analisis dan pembahasan data dilakukan sesuai dengan konsep deskriptif korelasional. Berdasarkan penelitian yang dilakukan dapat diringkas sebagai berikut. Pertama, ada hubungan yang signifikan antara minat membaca, keterampilan menulis berita siswa kelas VIII SMP Negeri 24 Padang. Kedua, ada hubungan yang signifikan antara motivasi belajar dan keterampilan menulis berita siswa kelas VIII. Ketiga, ada hubungan yang signifikan antara minat baca dan motivasi belajar bersama dengan kemampuan menulis berita siswa.

Kata kunci: membaca, motivasi belajar, keterampilan menulis berita

\section{PENDAHULUAN}

Tujuan utama pembelajaran keterampilan bahasa Indonesia dalam Kurikulum Tingkat Satuan Pendidikan (KTSP) di Sekolah Menengah Pertama yakni mengembangkan empatketerampilan berbahasa. Keempat keterampilan tersebut ialah keterampilan membaca, berbicara, menyimak, dan berbahasa saling berhubungan atau berkaitan. Keterampilan menulis. Keempat keterampilan berbahasa tersebut saling berkaitan dan perlu ditingkatkan agar siswa mampuberkomunikasi secara lisan maupun tulisan dengan baik.

Keterampilan menulis sebagai salah satu aspek keterampilan berbahasa penting untuk dikuasai siswadalam meningkatkan kemampuan intelektual siswa. Keterampilan menulis menuntut siswa untuk mampu mengungkapkan gagasan dan pemikirannya dalam suatu kerangka berpikir yang logis dan sistematis.

Berdasarkan Kurikulum Tingkat Satuan Pendidikan (KTSP) tahun 2006, salah satu keterampilan menulis di kelas VIII pada semester genap ialah keterampilan menulis berita. Keterampilan menulis terse- but terdapat dalam Standar Kompetensi (SK) ke-12 yang berbunyi "mengungkapkan informasi dalam bentuk rangkuman, teks berita, slogan/poster" dengan Kompetensi Dasar (KD) ke-12.2 yang berbunyi "menulis teks berita secara singkat, padat, dan jelas.

Berita ditulis untuk memberi- kan laporan tentang fakta dan ide yang dapat menarik perhatian pembaca. Berita dapat juga dikatakan sebagai peristiwa 
atau kehidupan yang benar-benar terjadi dalam waktu yang baru, yang mempunyai nilai kejutan, sehingga memenuhi rasa ingin tahu orang banyak.Fakta yang diungkapkan dalam menulis berita harus mengenai kejadian atau peristiwa yang faktual.

Melalui wawancara dengan guru mata pelajaran bahasa Indonesia kelas VIII di SMP Negeri 24 Padangditemukan masalah tentang pembela- jaran menulis berita. Nilai rata-rata keterampilan menulis berita siswa kelas VIII SMP Negeri 24 Padang berjumlah 65,50. Sementara itu, Kriteria Ketuntasan Minimal (KKM) yang ditetapkan ialah 75. Rendahnya keterampilan menulis berita siswa disebabkan karena siswa tidak mengungkapkan peristiwa atau kejadian secara faktual dan belum memenuhi persyaratan teknis menulis berita yakni $5 \mathrm{~W}+1 \mathrm{H}$ yakni what (apa), who (siapa), where (dimana), when (kapan), why (kenapa), dan how (bagaimana). Kurangnya keefektifan kalimat pada keterampilan menulis berita siswa.Kesalahan ejaan yang digunakan siswa.Selain itu, setiap kali siswa diberi tugas untuk mengarang terlihat banyak siswa yang mengeluh dan menganggap menulis adalah kegiatan yang sangat sulit dan membosankan. Hal tersebut terjadi karena kurangnya kosa kata yang dimiliki siswa sehingga siswa mengalami kesulitan dalam mengembangkan ide cerita.

Minat baca merupakan salah satu faktor penting yang harus ditumbuhkan kepada siswa ketika mereka harus menguasai keterampilan menulis. Minat baca sebagai kecenderungan jiwa yang diperoleh secara bertahap untuk merespon secara selektif, positif, dan disertai dengan rasa puas terhadap hal-hal khusus yang dibaca. Apabila siswa berminat terhadap suatu bacaan, maka siswa akan bersungguh-sungguh membaca bacaan yang diminati untuk mendapatkan informasi atau tujuan lain dari membaca. Tercurahnya perhatian siswa pada kegiatan membaca dengan sendirinya telah membawa siswa ke suasana aktif dalam pembelajaran. Secara tidak langsung hal ini dapat menambah pembendaharaan kosa kata siswa yang digunakan dalam rangkaian menulis berita.

Berdasarkan pengamatan dan wawancara informal dengan kepala pustaka dan guru Bahasa Indonesia SMP Negeri 24 Padang.Diperoleh informasi tentang beberapa faktor mengenai minat baca siswa di SMP Negeri 24 Padang, khususnya pada kelas VIII adalah sebagai berikut. Pertama, sarana yang terbatas karena koleksi bacaan di perpustakaan masih terbatas.Kedua, materi bacaan yang tidak menarik, sehingga siswa lebih memilih membaca cerita humor dan 
komik dibandingkan membaca surat kabar. Ketiga, kurangnya kesadaran siswa terhadap pentingnya membaca, sehingga pembendaharaan kosa kata siswa dalam menulis berita tidak bertambah.

Selanjutnya, faktor lain yang berperan penting dalam kegiatan menulis adalah motivasi belajar. Motivasi timbul karena adanya minat dari siswa. Motivasi merupakan hal yang penting dalam proses belajar karena motivasi bukan hanya sebagai penggerak tingkah laku, namun juga mengarahkan dan memperkuat tingkah laku dalam belajar. Motivasi adalah kekuatan, baik dari dalam maupun dari luar yang mendorong seseorang untuk mencapai tujuan tertentu yang telah ditetapkan sebelumnya.

Berdasarkan fenomena di atas peneliti melihat bahwa adanya permasalahan dalam keterampilan menulis berita. Hal ini mendorong peneliti untuk mengetahui gambaran secara pasti dan mendalam mengenai minat baca, motivasi belajar, dan keterampilan menulis siswa kelas VIII SMP Negeri 24 Padang.

Berdasarkan uraian di atas tujuan penelitian ini adalah menjelas- kan hal berikut. Pertama, hubungan minat baca dengan keterampilan menulis berita siswa kelas VIII SMP Negeri 24 Padang. Kedua, hubungan motivasi belajar dengan keterampilan menulis berita siswa kelas VIII SMP Negeri 24 Padang.Ketiga, hubungan minat baca dan motivasi belajar dengan keterampilan menulis berita siswa kelas VIII SMP Negeri 24 Padang.

\section{Metode}

Jenis penelitian ini adalah kuantitatif, dengan menggunakan rancangan deskriptif korelasional.Penelitian deskriptif merupakan penelitian yang bermaksud untuk melukiskan situasi atau kejadian-kejadian secara sistematis, faktual dan akurat.Penelitian korelasional adalah penelitian yang berusaha mendeteksi tingkat keterkaitan variansi-variansi suatu variabel dengan variansivariansi pada varia- belnya.

Secara deskriptif, penelitian ini mendeskripsikan data dari semua variabel yang ada, yakni minat baca, motivasi belajar dan keterampilan menulis berita.Secara korelasional penelitian ini berupaya mencari hubungan antara minat baca dan motivasi belajar dengan keterampilan menulis berita. Dari 
hubungan tersebut, akan dianalisis lebih lanjut untuk mencari besarnya sumbangan dari tiap-tiap variabel bebas ( $\mathrm{X} 1$ dan $\mathrm{X} 2$ ) dengan variabel terikat (Y). Pada penelitian ini minat baca, sebagai variabel bebas satu $\left(X_{1}\right)$, motivasi belajar sebagai variabel bebas $\left(\mathrm{X}_{2}\right)$, sedangkan menulis berita sebagai variabel terikat $(\mathrm{Y})$ siswa kelas VIII SMP Negeri 24 Padang.

Populasi dalam penelitian ini adalah siswa kelas VIII SMP Negeri 24 Padang yang terdaftar pada tahun ajaran 2013/2014.Jumlah siswa kelas VIII yang terdaftar pada tahun ajaran tersebut adalah 252 siswa yang tersebar dalam delapan kelas.

Penarikan sampel dalam penelitian ini mengacu pada pendapat Yusuf (2007:201) dengan menggunakan teknik proportionalrandom sampling. Untuk menentukan berapa jumlah sampel pada setiap kelas digunakan perbandingan antara jumlah kelompok dibagi jumlah total (jumlah populasi) dan dikaitkan dengan jumlah sampel yang telah ditetapkan sebelumnya. Jadi, diperoleh 40 siswa atau 5 siswa pada tiap kelas.

Jadi, sebelum penelitian dilakukan terlebih dulu dilakukan uji coba terhadap angket minat baca dan motivasi belajar. Uji coba dilakukan untuk menentukan validitas item dan reliabilitas tes agar data yang diberikan dapat dipertanggung- jawabkan keabsahannya.

Sebelum data dianalisis lebih lanjut perlu dilakukan uji persyaratan analisis, yaitu uji normalitas dan uji linearitas data. Uji normalitas data dilakukan untuk mengetahui normal tidaknya data yang diperoleh dengan menggunakan Chi Kuadrat Riduwan (2012:184). Uji linearitas dilakukan untuk mengetahui dua variabel mempunyai hubungan yang linear atau tidak secara signifikan. Riduwan (2012:184) menjelaskan bahwa linier berarti data yang dihubungkan berbentuk garis linier, maka perlu uji linieritas.

Data skor dalam penelitian ini dikelompokkan menjadi tiga.Data skor kelompok pertama dan kedua adalah data skor yang terkait dengan variabel bebas $\left(\mathrm{X}_{1}\right.$ dan $\left.\mathrm{X}_{2}\right)$ dan data skor kelompok ketiga terkait dengan variabel terikat (Y).Data skor yang tergolong ke dalam variabel bebas adalah nilai angket minat baca $\left(X_{1}\right)$ dan nilai angket motivasi belajar $\left(X_{2}\right)$, sedangkan data skor yang tergolong ke dalam variabel terikat adalah nilai keterampilan menulis berita $(\mathrm{Y})$. Ketiga data skor tersebut dideskripsikan dalam bentuk distribusi frekuensi yang terdiri atas penghitungan rata-rata, modus, median, simpangan baku, dan range. 
Instumen yang digunakan untuk mengumpulkan data dalam penelitian ini terdiri dari dua instrumen, yaitu angket dan tes unjuk kerja. Angket digunakan untuk mengetahui minat baca dan motivasi belajar siswa, sedangkan tes unjuk kerja digunakan untuk keterampilan menulis berita siswa.

Kisi-kisi tes keterampilan menulis berita berdasarkan pendapat sebagai berikut.Pertama, Siregar (1987:163), yaitu judul berita. Kedua, Chaer (2010:25), yaitu teras berita. Ketiga, Assegaf (1991:49), yaitu kelengkapan unsur 5W+1H.Keempat, Keraf (1993:38), yaitu kepaduan gagasan. Kelima,Semi (2009:151), yaitu ejaan.

Kisi-kisi angket minat baca menurut Brata (1995:18), yakni(1) memiliki kesadaran dan minat yang tinggi terhadap membaca, (2) usaha yang dilakukan untuk memenuhi minat baca, (3) kebiasaan membaca, dan (4) memilih bahan bacaan yang baik.

Kisi-kisi angket motivasi belajar menurut Sardiman (2005:83), yakni (1) tekun dalam belajar, (2) ulet dalam belajar, (3) perhatian dalam belajar, (4) berprestasi dalam belajar, (5) mandiri dalam belajar.

\section{Hasil Penelitian dan Pembahasan}

Berdasarkan hasil analisis data diperoleh temuan penelitian sebagai berikut. Pertama, minat baca berhubungan secara signifikan dengan keterampilan menulis berita siswa kelas VIII SMP Negeri 24 Padang.Kedua, motivasi belajar berhubungan secara signifikan dengan keterampilan menulis berita siswa kelas VIII SMP Negeri 24 Padang. Ketiga, minat baca dan motivasi belajar secara bersama-sama berhubungan secara signifikan dengan keterampilan menulis berita siswa kelas VIII SMP Negeri 24 Padang.

\section{Hubungan Minat Baca dengan Keterampilan Menulis Berita}

Berdasarkan hasil penelitian di SMP Negeri 24 Padang ditemukan bahwa koefisien korelasi minat baca dengan keterampilan menulis berita tergolong cukup ialah sebesar 0,448. Selanjutnya, terdapat hubungan yang signifikan antara minat baca dengan keterampilan menulis berita sebesar $20 \%$. Hal ini menunjukkan bahwa keterampilan menulis berita siswa dipengaruhi oleh minat baca mereka.Oleh karena itu, minat baca harus mendapatkan perhatian yang lebih dari siswa dan guru di SMP Negeri 24 Padang. 
Hubungan minat baca dengan keterampilan menulis berita memiliki persamaan regresi sederhana $\hat{Y}=49,66+0,354 X_{1}$. Hal ini menunjukkan bahwa pada saat minat baca belum memberikan sumbangan terhadap keterampilan menulis berita, nilai keterampilan menulis berita telah ada sebesar 49,66 . Pada saat minat baca memberikan satu nilai, maka nilai keterampilan menulis berita akan berubah sebesar 49,66 +0,354X1. Oleh karena itu, semakin tinggi minat baca yang dimiliki siswa, maka semakin tinggi keterampilan menulis berita mereka.

Temuan penelitian ini sejalan dengan pendapat Indriastuti (dalam Tarigan, dkk., 2011:95) yang menyatakan bahwa peran minat dalam membaca sangat penting. Minat siswa sering timbul karena keinginannya memahami bacaan atau menerima informasi dari lingkungan. Mengembangkan minat baca siswa hendaknya dilakukan pada saat pendidikan berlangsung.Dalam meningkatkan minat baca, peran pendidik sangat penting. Guru harus mampu mengatur program pendidikan yang mendukung usaha tersebut. Guru memberikan bahan bacaan yang sesuai dengan minat bacaan siswa. Hal tersebut bisa mendorong minat baca siswa.

Berdasarkan penelitian yang telah terdahulu yang dilakukan oleh Yuliarni (2011) terlihat bahwa hasil temuan sekarang persentasenya lebih rendah daripada persentase penelitian terdahulu. Tingkat pencapaian angket minat baca pada penelitian ini sebesar $20,07 \%$, sedangkan pada penelitian terdahulu yang telah dilakukan oleh Yuliarni (2011) tingkat pencapaian angket minat baca sebesar $44,20 \%$. Perbedaan persen- tase yang diperoleh pada penelitian ini dengan penelitian terdahulu disebabkan karena prediksi dan generalisasi yang dilakukan dari hasil penelitian ini bukanlah merupakan hal yang pasti karena berganti sampel mungkin saja berganti hasil penelitian. Temuan ini juga menegaskan bahwa di satu sisi, minat baca memberikan sumbangan terhadap keterampilan menulis berita, namun di sisi lain temuan ini juga mengungkapkan bahwa minat baca siswa perlu ditingkatkan.

\section{Hubungan Motivasi Belajar dengan Keterampilan Menulis Berita}

Berdasarkan hasil penelitian di SMP Negeri 24 Padang ditemukan bahwa koefisien korelasi motivasi belajar dengan keterampilan menulis berita tergolong cukup ialah sebesar 0,413 . Selanjutnya, terdapat hubu- ngan yang signifikan 
antara motivasi belajar dengan keterampilan menulis berita sebesar $17 \%$. Hal ini menunjukkan bahwa keterampilan menulis berita siswa dipengaruhi oleh motivasi belajar. Oleh karena itu, motivasi belajar harus mendapatkan perhatian yang lebih dari siswa dan guru di SMP Negeri 24 Padang.

Hubungan motivasi belajar dengan keterampilan menulis berita memiliki persamaan regresi seder- hana $\hat{Y}=48,68+0,37 X_{2}$. Hal ini menunjukkan bahwa pada saat motivasi belajar belum memberikan pengaruh terhadap keterampilan menulis berita, nilai keterampilan menulis berita telah ada sebesar 48,68 . Pada saat motivasi belajar memberikan satu nilai, maka nilai keterampilan menulis berita akan berubah sebesar 48,68 +0,37X2. Oleh karena itu, semakin banyak motivasi belajar yang dimiliki siswa, maka semakin tinggi keterampilan menulis berita mereka.

Temuan penelitian ini sejalan dengan pendapat Mc. Donald (dalam Sardiman, 2008:73) motivasi adalah perubahan energi dalam diri seseorang yang ditandai dengan munculnya feeling dan didahului dengan tanggapan terhadap adanya tujuan. Pengertian ini mengandung tiga elemen penting: (a) motivasi mengawali terjadinya perubahan energi pada diri setiap individu, (b) motivasi ditandai dengan munculnya rasa, afeksi seseorang, dan (c) motivasi akan dirangsang karena adanya tujuan.

Berdasarkan penelitian terdahulu yang telah dilakukan oleh Afnita (2005) terlihat bahwa hasil temuan sekarang persentasenya lebih besar daripada persentase penelitian terdahulu. Tingkat pencapaian angket motivasi belajar pada penelitian ini sebesar $17,05 \%$, sedangkan pada penelitian terdahulu yang telah dilakukan oleh Afnita (2005) tingkat pencapaian angket motivasi belajar sebesar $11,50 \%$.

Perbedaan persentase yang diperoleh pada penelitian ini dengan penelitian terdahulu disebabkan karena prediksi dan generalisasi yang dilakukan dari hasil penelitian ini bukanlah merupakan hal yang pasti karena berganti sampel mungkin saja berganti hasil penelitian.Temuan ini juga menegaskan bahwa di satu sisi, motivasi belajar memberikan sumbangan terhadap keterampilan menulis berita, namun di sisi lain temuan ini juga mengungkapkan bahwa motivasi belajar siswa perlu ditingkatkan. 


\section{Hubungan Minat Baca dan Motivasi Belajar secara Bersama-sama dengan Kete- rampilan Menulis Berita}

Berdasarkan hasil penelitian di SMP Negeri 24 Padang ditemukan bahwa koefisien korelasi minat baca dan motivasi belajar secara bersama-sama dengan keterampilan menulis berita tergolong cukup ialah sebesar 0,55. Selanjutnya, minat baca dan motivasi belajar secara bersama-sama memberikan sumbangan yang signifikan dengan keterampilan menulis berita sebesar 30,25\%. Hal ini menunjukkan bahwa keterampilan menulis berita siswa dipengaruhi oleh minat baca dan motivasi belajar mereka. Di samping itu, ada 69,75\% lagi variabel lain yang sebenarnya menentukan keberhasilan keterampilan menulis berita.

Hubungan minat baca dan motivasi belajar secara bersama-sama terhadap keterampilan menulis berita dapat dinyatakan dengan persamaan regresi $\hat{Y}=33,93+0,294 X_{1}+0,295 X_{2}$. Hal ini menunjukkan bahwa pada saat minat baca dan motivasi belajar belum memberikan pengaruh terhadap keterampilan menulis berita, nilai keterampilan menulis berita telah ada sebesar 33,94. Pada saat minat baca dan motivasi belajar memberikan satu nilai, maka nilai keterampilan menulis berita akan berubah sebesar 33,93+0,294 0,295 Oleh karena itu, semakin tinggi minat baca dan motivasi belajar, maka semakin tinggi keterampilan menulis berita siswa.

Berdasarkan besar hubungan minat baca dan motivasi belajar dengan keterampilan menulis berita, dapat disimpulkan bahwa minat baca memiliki hubungan yang lebih besar dengan keterampilan menulis berita dibandingkan dengan motivasi belajar.Hal ini disebabkan minat baca mempengaruhi motivasi belajar siswa. Siswa yang memiliki minat baca yang tinggi pada bacaan akan meningkatkan motivasi belajarnya dan akan mempengaruhi keteram- pilan menulis berita. Siswa yang memiliki minat baca yang tinggi akan menambah penguasaan kosa kata dan wawasannya.Selain itu, dapat juga disimpulkan bahwa minat baca dan motivasi belajar, baik secara sendiri-sendiri maupun bersamasama memberikan sumbangan terhadap keterampilan menulis berita. Oleh karena itu, apabila ingin meningkatkan keterampilan menulis berita, maka minat baca dan motivasi belajar mereka harus ditingkatkan.

Selain itu, temuan ini juga menegaskan bahwa minat baca dan motivasi belajar memang memberikan sumbangan terhadap keterampilan menulis berita, namun banyak faktor lain yang juga menentukan keterampilan berita siswa. 
Dilihat tingkat pencapaian minat baca dan motivasi belajar terhadap keterampilan menulis di dalam penelitian ini sebesar 30,25\%\%, sedangkan pada penelitian terdahulu yang telah dilakukan oleh Shaumia (2012) tingkat pencapaian minat baca dan motivasi belajar terhadap keterampilan menulis sebesar 24,4\%. Berdasarkan penelitian yang telah dilakukan oleh Shaumia (2012) terlihat bahwa hasil temuan sekarang persentasenya lebih besar daripada persentase penelitian terdahulu. Perbedaan persentase yang diperoleh pada penelitian ini dengan penelitian terdahulu disebabkan karena berganti sampel mungkin saja berganti hasil penelitian.

Seseorang yang memiliki minat baca akan lebih banyak buku yang pernah dibacanya daripada yang kurang memiliki minat baca. Dengan banyaknya bacaan yang telah dibacanya akan menambah pengetahuan yang dimiliki oleh siswa dan siswa akan memiliki perbendaharaan kosakata yang banyak. Ini akan sangat berpengaruh terhadap keterampilan mereka dalam menulis. Menulis membutuhkan perbendaharaan kata yang banyak, sehingga memudahkan mereka dalam menulis. Soedarso (2005:58) mengatakan bahwa kemampuan tiap orang dalam memahami apa yang dibaca berbeda-beda, salah satunya tergantung pada perbendaharaan kata, minat, jangkauan mata, kecepatan interpretasi dan tujuan membaca tersebut. Dengan adanya saling keterkaitan antara minat baca, motivasi belajar dan menulis berita, guru berperan cukup besar dalam peningkatan ketiga variabel ini. Sebagai contoh, dalam memotivasi siswa untuk belajar guru dapat memberikan teknik-teknik yang bervariasi dalam pembelajaran Bahasa Indonesia.

\section{Simpulan}

Penelitian ini membahas tentang hubungan minat baca dan motivasi belajar dengan keterampilan menulis berita siswa kelas VIII SMP Negeri 24 Padang.Berdasarkan hasil penelitian dan pembahasan yang dikemukakan, diperoleh simpulan sebagai berikut.

Pertama, terdapat hubungan yang signifikan antara minat baca dengan keterampilan menulis berita siswa kelas VIII SMP Negeri 24 Padang. Temuan penelitian ini menunjukkan bahwa semakin tinggi minat baca siswa, maka semakin tinggi keterampilan menulis berita mereka.Hal ini disebabkan minat 
memberikan dorongan terhadap kebiasaan membaca.Oleh karena itu, guru harus memperhatikan minat baca siswa dan memberikan dorongan kepada siswa untuk selalu melakukan kegiatan membaca agar keterampilan menulis berita mereka meningkat.

Kedua, terdapat hubungan yang signifikan antara motivasi belajar dengan keterampilan menulis berita siswa kelas VIII SMP Negeri 24 Padang.Berdasarkan temuan penelitian yang diperoleh motivasi belajar siswa harus ditingkatkan dengan menumbuhkan motivasi tersebut pada pribadi siswa. Salah satu cara yang dapat dilakukan yaitu, guru harus mampu memberikan dorongan agar bisa menumbuhkan motivasi belajar siswa. Apabila motivasi belajar tinggi, maka keterampilan menulis karangan narasi akan tinggi pula. Sebaliknya, apabila motivasi belajar rendah, maka keterampilan menulis karangan narasi akan rendah pula.

Ketiga, terdapat hubungan yang signifikan antara minat baca dan motivasi belajar secara bersama-sama dengan keterampilan menulis berita siswa kelas VIII SMP Negeri 24 Padang. Temuan penelitian ini menunjukkan bahwa keterampilan menulis berita siswa akan meningkat apabila minat baca dan motivasi belajar mereka juga meningkat. Hal ini disebabkan minat baca dan motivasi belajar diperlukan dalam keterampilan menulis berita. Oleh karena itu, disarankan kepada guru agar lebih fokus memberikan dorongan untuk membaca kepada siswa dan memberikan pelatihan-pelatihan yang memungkinkan siswa memperbanyak penguasaan kosa- katanya guna meningkatkan keteram- pilan menulis berita siswa.

Bertolak dari hasil penelitian, maka disarankan hal-hal sebagai berikut. Pertama, siswa hendaknya meningkatkan kegiatannya dalam hal membaca. Hal itu dilakukan agar siswa memperoleh banyak ilmu dan pengetahuan. Siswa juga harus paham dengan bacaan yang telah dibaca, sehingga dengan ilmu yang dimiliki siswa dapat meningkatkan keterampilan khususnya keteram- pilan menulis berita. Siswa diharapkan untuk mengembangkan keterampilan yang telah dimiliki dan bagi yang masih kurang untuk tetap berlatih. Kedua, guru diharapkan dapat meningkatkan profesionalnya sebagai pendidik. Guru harus mampu mengajak dan menyakinkan siswa bahwa setiap materi yang terdapat dalam buku-buku majalah maupun koran sangat bermanfaat bagi siswa. Selain itu, meskipun guru hanya menjadi fasilitator tetapi guru juga harus memberikan 
Ria, Atmazaki, Abdurahman, Hubungan Minat Baca

pemahaman konsep kepada siswa, sehingga siswa memiliki pegangan yang jelas dalam praktik.

\section{Rujukan}

Assegaff, D. H. (1991). Jurnalistik Masa Kini. Jakarta: Ghalia Indonesia.

Chaer, A. (2010). Bahasa Jurnalistik. Jakarta: Rineka Cipta.

Riduwan. (2012). Dasar-Dasar Statistik. Bandung: Alfabeta.

Sardiman, A. M. (2005). Interaksi dan Motivasi Belajar-Mengajar. Jakarta: Raja Grafindo.

Sardiman. (2008). Interaksi dan Motivasi Belajar Mengajar. Jakarta: PT. Raja Grapindo Persada.

Semi, M. A. (1995). Menulis Kreatif. Padang: Angkasa Padang.

Siregar, R. (1987). Bahasa Indonesia Jurnalistik. Jakarta: Pustaka Grafika.

Suryabrata, S. (1995). Psikologi Pendidikan. Jakarta: Raja Grafindo Persada.

Tarigan, H. G., dkk. (2011). Membaca dalam Kehidupan (Edisi Revisi).Bandung: Angkasa.

Yusuf, A. M. (2007). Metodologi Penelitian. Padang: UNP Press. 